CZU 633.11+632.938:575

https://doi.org/10.53040/gppb7.2021.56

\title{
VARIABILITATEA GENOTIPURILOR DE COLECTIE DE GRÂU (Triticum aestivum L.) ÎN BAZA SENSIBILITĂŢII LA UNELE MALADII FUNGICE
}

\author{
Cristea Nicolae, Lupaşcu Galina, Gavzer Svetlana \\ Institutul de Genetică, Fiziologie şi Protecţie a Plantelor, Chișinău, Republica Moldova \\ e-mail: galina.lupascu@igfpp.md
}

\begin{abstract}
The common wheat genotypes under study showed a differentiated variability in terms of susceptibility to septoria, brown rust, spike fusariosis, which made it possible to differentiate them into clusters and identify those with higher resistance to these diseases. Based on the assessments from 2020-2021, the varieties Trubion, Numitor, Urbanus, Python, Miranda, Centurion, Amor, Aneta, Neven, Messino, Nasnaga, Tika-Taka, Judița, Avenue, Speranța, Dacia, Transilvania, Selania, Avânt which have shown resistance to extreme drought, fungal diseases and high indices of the spike productivity elements can be recommended as the initial material for the breeding programs.
\end{abstract}

Key words: common wheat, septoriosis, brown rust, spike fusariosis, variability.

\section{Introducere}

Grâul comun de toamnă (Triticum aestivum L.) este o cultură deosebit de importantă pentru securitatea alimentară globală, producţia de boabe contribuind cu circa $20 \%$ din totalul caloriilor şi proteinelor alimentare din întreaga lume și reprezintă una dintre principalele culturi cerealiere în Republica Moldova.

De rând cu potenţialul genetic de producţie înalt al soiurilor nou create, o actualitate deosebită capătă şi capacitatea de adaptare a acestora la schimbările climatice tot mai severe din ultimul deceniu. Este de menţionat că schimbările bruşte de temperatură şi umiditate predispun culturile agricole, inclusiv grâul, la maladii fungice. Printre acestea, pot fi menţionate septorioza, rugina brună şi fuzarioza spicului.

Septorioza. Maladia este cauzată de fungul Mycosphaerella graminicola (forma asexuată sau anamorfă - Septoria tritici). Se manifestă prin leziuni necrotice ale suprafeţei frunzelor şi tulpinilor, iar după invadarea celulei provoacă colapsul acesteia. Aplicarea extensivă a fungicidelor sporeşte costurile economice ale septoriozei în lume [6]. Există date despre creşterea severităţii septoriozei, cu preponderenţă la soiurile de grâu timpurii şi cu talie nu prea înaltă $[5,13]$. Soiurile cu talie înaltă şi care se maturizează mai târziu prezintă un nivel mai jos de îmbolnăvire de septorioză, ceea ce urmează a fi luat în considerare în cadrul selectărilor. O contribuţie pentru intensitatea septoriozei îl are factorul de genotip. Coeficientul de heritabilitate a rezistenţei în sens restrâns constituie $42 \%$, ceea ce denotă aportul favorabil al acţiunilor aditive din planta gazdă [2].

$\mathrm{Au}$ fost identificate 13 gene pentru rezistenţă la septorioză şi unii markeri moleculari ai acesteia. Astfel, genele rezistenţei Stb1-8, retroîncrucişate cu 2 soiuri susceptibile de grâu au demonstrat că gena Stb3 se manifestă că dominantă, iar gena Stb 2 - atât dominantă cât şi recesivă [4, 7]. Rezistenţa la maladie poate fi controlată oligogenic, cu specificitate pentru o anumită izolată [11], dar şi cantitativă - poligenică [5].

Expresia genelor de rezistenţă pentru $M$. graminicola variază pe durata ontogenezei şi până în prezent mecanismul acesteia este incert. [1]. Intensitatea septoriozei manifestă o largă variabilitate printre genotipurile de grâu. Diferenţele în ceea ce priveşte capacitatea combinativă generală şi specifică a soiurilor de grâu, denotă importanţa efectelor aditive şi non-aditive în formarea reacţiei de rezistenţă şi heritabilităţii acesteia. S-a demonstrat şi manifestarea efectelor dominante în controlul rezistenţei la septorioză [12]. Conform altor date, capacitatea combinativă generală a grâului pentru rezistenţa la septorioză a fost mai înaltă decât cea specifică, ceea ce relevă că efectul genelor aditive este major în răspunsul la atacul patogenului [14].

Rugina brună cauzată de Puccinia recondita Rob. ex Desm. f.sp. tritici, este cea mai răspândită dintre rugini la grâul comun. Inhibă procesul de fotosinteză, activează respiraţia şi transpiraţia plantei. Ca rezultat diminuează numărul boabelor în spic, masa bobului şi cantitatea de proteină în boabe. Patogenul este adaptat la diverse condiţii de mediu, din care motiv este întâlnit în diferite zone de cultivare a grâului. Soiurile susceptibile pot suporta pierderi de circa 5-15\% sau chiar mai mult, acestea depinzând de etapa de dezvoltare a plan- 
tei la care a fost afectată. Rezistenţa genetică este cea mai preferabilă metodă de reducere a pierderilor de roadă la grâu. Au fost identificate şi localizate 51 de gene ale rezistenţei, expresia cărora depinde de genetica interacţiunii gazdă x parazit, condiţiile de temperatură, etapa de dezvoltare a plantei şi interacţiunea genelor rezistenţei cu genele supresoare sau alte gene ale rezistenţei din genomul de grâu [3].

Utilizarea rezistenţei genetice parţiale, nespecifice, de plantă adultă reprezintă o premiză pentru mărirea durabilităţii rezistenţei grâului, independent de evoluţia climei şi a virulenţei agentului patogen $[8,9]$. S-au observat efecte aditive pentru diferite gene care conferă rezistenţă la rugină brună, şi totodată, efecte epistatice - pentru tipul de infecţie [10].

Fuzarioza spicului este o boală devastatoare pentru grâu, cauzată de un șir de specii din genul Fusarium care de rând cu pagubele de producție, mai polueză cariopsele cu micotoxine, astfel acestea devenind toxice pentru consumatori [16].

Mai multe ciuperci endofitice colonizează, de asemenea, spicele de grâu asimptomatic. Ciupercile patogene şi comensuale valorifică și concurează pentru aceeași nișă și astfel influențează viabilitatea plantelor. Elucidarea dinamicii naturale a comunității fungice și modul în care speciile prestabilite reacționează la atacul de agenți patogeni poate oferi informații utile despre biologia bolii și utilizarea potențială a unora dintre aceste organisme endofite în strategiile de combatere a bolilor [15].

În legătură cu faptul că majoritatea soiurilor cultivate de grâu manifestă sensibilitate înaltă la septorioză, rugină brună, fuzarioza spicului, scopul prezentelor cercetări a constat în stabilirea gradului de atac al bolilor menționate, larg răspândite în Republica Moldova un set de genotipuri de grâu comun de toamnă de diferită origine ecologo-geografică și identificarea celor rezistente.

\section{Materiale și metode}

În calitate de material pentru cercetare au servit 47 de genotipuri de grâu comun de toamnă de diferită origine ecologo-geografică care în anul deosebit de secetos 2020 au manifestat rezistență la condițiile ambientale și indici productivitate relativ înalţi.

Aprecierea gradului de atac de septorioză și rugină brună s-a efectuat în scara de 5 trepte: $1-10 \%$ .. 5->50\% din suprafața frunzei - atacată; 0 - lipsa semnelor de atac (Fig.).

În anul 2021, temperatura joasă pe durata lunii aprilie a condus la apariţia întârziată a bolilor foliare. Primele simptome de septorioză au fost înregistrate la 7 iunie doar la unele genotipuri.

Este de menționat că odată cu creșterea temperaturii, bolile foliare s-au intensificat, în special septorioza, dezvoltarea puternică a căreia a obstrucționat într-o oarecare măsură dezvoltarea ruginii brune (date înregistrate la 21.06.21).

Frecvența atacului de fuzarioza spicului (Fig.) s-a înregistrat la sfârșitul lunii iunie 2021.

Datele înregistrate au fost prelucrate statistic în pachetul de soft STATISTICA 8.

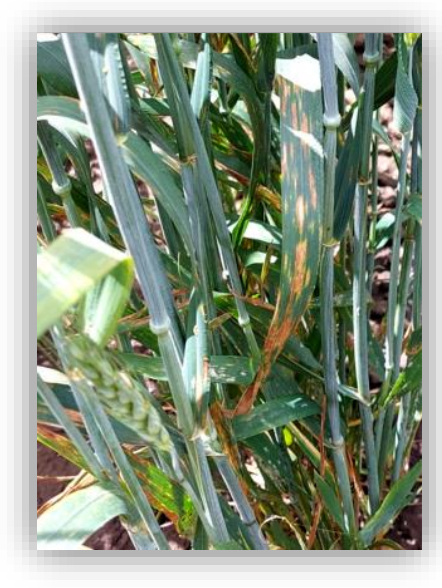

Septorioz $\breve{a}$

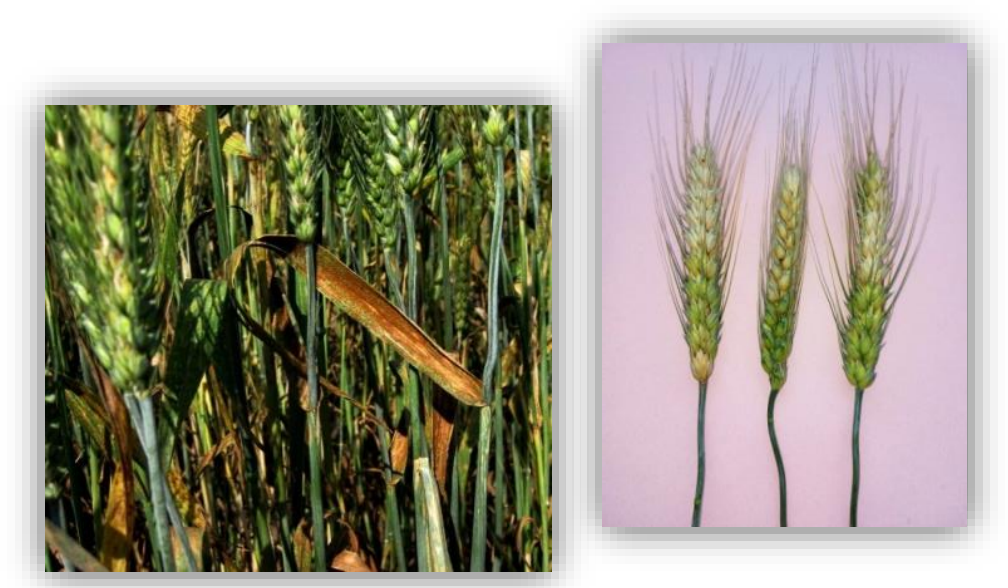

Rugină brună
Fuzarioza spicului

Fig. Maladii fungice la grâul comun de toamnă 


\section{Rezultate și discuții}

S-a constatat că media gradului de atac de septorioză, rugină brună și a frecvenței fuzariozei spicului (\%) pentru setul de genotipuri de grâu aflat în studiu a constituit 4,20; 1,43 și 6,27\%, respectiv (Tab. 1).

Tabelul 1. Atacul setului de genotipuri de grâu comun de boli fungice

\begin{tabular}{|l|c|c|c|c|}
\hline Maladie & Medie & Minimum & Maximum & V, \% \\
\hline Septorioză, grad & $4,20 \pm 0,10$ & 2,50 & 5,00 & 16,55 \\
\hline Rugină brună, grad & $1,43 \pm 0,09$ & 0,00 & 3,00 & 44,20 \\
\hline Fuzarioza spicului, \% & $6,27 \pm 0,34$ & 1,81 & 15,80 & 37,38 \\
\hline
\end{tabular}

Date obținute denotă că genotipurile de grâu au înregistrat o variabilitate înaltă în ceea ce privește atacul de rugină brună (44,2\%) și fuzarioza spicului (37,4\%) și variabilitate medie pentru septorioză (16,6\%).

Prin analiză clusteriană (metoda $k$-mediilor) s-a constatat că cea mai înaltă capacitate de diferențiere a clusterelor a manifestat sensibilitatea la fuzarioza spicului. A fost identificat un cluster din 25 de soiuri, media gradului de atac al căruia pentru rugină brună și septorioză a constituit 1,5 și 4,02, respectiv, iar media frecvenței fuzariozei spicului (\%) - 4,7. Printre aceste soiuri pot fi menționate Trubion, Numitor, Urbanus, Python, Miranda, Centurion, Amor, Aneta, Neven, Messino, Nasnaga, Tika-Taka, Judița, Avenue, Speranța, Dacia, Transilvania, Selania, Avânt care manifestă totodată indici înalţi ai elementelor de productivitate ale spicului.

\section{Concluzii}

1. Genotipurile de grâu comun aflate în studiu au manifestat o variabilitate diferențiată în ceea ce privește sensibilitatea la septorioză, rugina bruna, fuzarioza spicului, ceea ce a făcut posibilă diferențierea lor în clustere și identificarea celor cu rezistență mai înaltă la bolile menționate.

2. În baza aprecierilor din anii 2020-2021, soiurile Trubion, Numitor, Urbanus, Python, Miranda, Centurion, Amor, Aneta, Neven, Messino, Nasnaga, Tika-Taka, Judița, Avenue, Speranța, Dacia, Transilvania, Selania, Avânt care au manifestat rezistență la secetă extremă, boli fungice și indici înalți ai elementelor de productivitate ale spicului pot fi recomandate în calitate de material iniţial pentru programele de ameliorare.

Cercetările au fost realizate în cadrul proiectului Programului de Stat 20.80009.7007.04 "Biotehnologii și procedee genetice de evaluare, conservare și valorificare a agrobiodiversității”, finanțat de Agenția Naţională pentru Cercetare și Dezvoltare.

\section{Bibliografie}

1. ADHIKARI, T.B. et al. Resistance of wheat to Mycosphaerella graminicola involves early and late peaks of gene expression. Physiol. and Mol. Plant Pathology, 2007, 71, p. 55-68.

2. ARRAIANO, L.S. et al. Resistance of wheat to septoria tritici blotch (Mycosphaerella graminicola) and associations with plant ideotype and the 1BL-1RS translocation. Plant Pathology, 2006, Vol. 55, Issue 1, p. 54-61.

3. BOŠKOVIC, J., BOŠKOVIC, M., PRIJIC, Z. Testing of wheat to durable resistance and survey approach for Puccinia recondita tritici. Genetika, 2008, Vol. 40, No. 2, p. 95-107.

4. CHARTRAIN, L. et al. Identification and location of Stb9, a gene for resistance to septoria tritici blotch in wheat cultivars Courtot and Tonic. Plant Pathology, 2009, 58, p. 547-555.

5. CHARTRAIN, L. et al. Partial resistance to septoria tritici blotch (Mycosphaerella graminicola) in wheat cultivars Arina and Riband. Phytopathology, 2004, 94, p. 497-504.

6. GHARBI, M.S., DEGHAIS, M., BEN AMAR, F. Breeding for resistance to Septoria tritici in durum wheat. Royo C. (ed.), Nachit M. (ed.), Di Fonzo N. (ed.), Araus J.L. (ed.). Durum wheat improve. in the Mediterr. region: New challenges. Zaragoza: CIHEAM, 2000, p. 397-401.

7. GOODWIN, S.B., THOMPSON, I. Development of Isogenic Lines for Resistance to Septoria tritici Blotch in Wheat. Czech J. Genet. Plant Breed., 47, 2011 (Special Issue), s. 98-101.

8. HERRERA-FOESSEL, S.A. et al. Genetic Analysis of Slow-Rusting Resistance to Leaf Rust in Durum Wheat. Crop Science, 2008, Vol. 48 nr 6, p. 2132-2140.

9. ITTU, M., ITTU, Gh. Unele aspecte ale ameliorării rezistenţei grâului la rugina brună în contextul schimbărilor climatice. Genetica şi ameliorarea plantelor. An. I.N.C.D.A. Fundulea, Vol. LXXVIII, nr 1, 2010, p. 17-24. 
10. LI, T., BAI, G.H., GU, S.L. A combination of leaf rust resistance gene Lr34 and lesion mimic gene $1 \mathrm{~m}$ significantly enhances adult plant resistance to Puccinia triticina in wheat. Chin. Sci. Bull., 2012, Vol. 57, nr 17, p. 2113-2119.

11. MCCARTNEY, C.A., BRÛLÉ-BABEL, A.L., LAMARI, L. Inheritance of race-specific resistance to Mycosphaerella graminicola in wheat. In: Phytopathology, 2002, 92, p. 138-144.

12. RAMEZANPOUR, S.S. et al. Estimation of combining abilities and heterosis of Septoria tritici blotch resistance in wheat genotypes. Austr. J. Crop Science, 2010, 4(7), p. 480-484.

13. SIMÓN, M.R., WORLAND, A.J., STRUIK, P.C. Influence of plant height and heading date on the expression of the resistance to septoria tritici blotch in near isogenic lines of wheat. Crop Sci., 2004, 44, p. 2078-85.

14. VAKILI BASTAM, S.H. et al. Inheritance of resistance to septoria tritici blotch (STB) in some Iranian genotypes of wheat (Triticum aestivum L.). Int. J. of Genet. and Mol. Biol., 2010, 2 (3), p. 34-42.

15. ROJAS, E.S. et al. Fusarium Head Blight Modifies Fungal Endophytic Communities During Infection of Wheat Spikes. Microbial Ecology, 2020, vol. 79, p. 397-408

16. PASQUALI, M. et al. A European database of Fusarium graminearum and F. culmorum trichothecene genotypes. Front Microbiol., 2016. https://doi.org/10.3489/fmicb.2016.00406 